\title{
Warunki \\ chińsko-europejskich koprodukcji filmowych
}

\author{
TOMASZ KOŻUCHOWSKI
}

Chińska kinematografia w XXI w. imponująco się rozwinęła i wyraźnie zaznaczyła swoją obecność w globalnym przemyśle filmowym. Jej dynamiczny postęp, zarówno w dziedzinie produkcji, dystrybucji, jak i projekcji oraz wpływ, jaki w ostatnich latach ma chociażby na amerykańskie blockbustery, zachęca, by przyglądać się jej z coraz większą uwagą. Niniejszy artykuł został poświęcony współpracy filmowej między Europą a Chinami, która powoli, ale systematycznie rozwija się, co daje szanse rozwoju kina zarówno na Starym Kontynencie, jak i w Azji.

Międzynarodowe koprodukcje to stosunkowo nowa gałąź funkcjonowania przemysłu filmowego w Państwie Środka. O ile jego wspólne przedsięwzięcia z Hollywoodem są coraz popularniejsze na rynku audiowizualnym, o tyle rozwijająca się współpraca Chin z krajami europejskimi wciąż stanowi zjawisko nie opisane. Warto więc zadać sobie kilka pytań: na jakich warunkach odbywa się ta współpraca, jakie są z niej korzyści, kto czerpie je w większym stopniu i czy cel tych działań jest dla obu stron taki sam? Czy filmy, które są efektem tego współdziałania wnoszą, cokolwiek do światowej kinematografii i czy mogą stanowić zagrożenie dla koprodukcji sino-hollywoodzkiej?

W ostatnich kilkunastu latach chiński rynek kinowy osiągnął bardzo silną pozycję na świecie, ustępując Amerykanom, ale zdecydowanie prześcigając rynki europejskie. Ten wzrost znaczenia Państwa Środka opisuje Marcin Adamczak: Jeszcze w pierwszych latach XXI wieku uktad sit na rynku światowym ksztattowat się w sposób charakterystyczny dla drugiej połowy wieku XX. Zdecydowanie największy byt rynek amerykański, a następnie rynki amerykańskich sojuszników czasu zimnej wojny: Japonii oraz pięciu państw zachodnioeuropejskich-Francji, Wielkiej Brytanii, Niemiec, Włoch i Hiszpanii. Byty to terytoria kluczowe dla powodzenia na rynku światowym, dystansujace pozostałe choćby dlatego, że bardzo duży rynek indyjski nie dysponowat jednak tak mocna waluta, jak wskazane wcześniej kraje, co wptywało na potencjał zysków denominowanych $w$ dolarach. Dopiero w 2008 roku, przypadkowo także pierwszym roku kryzysu finansowego w USA, przynoszacego relatywne osłabienie mocarstwa znad Potomacu, Chiny trafiaja do pierwszej dziesiątki największych rynków kinowych. Od roku 2012 nieprzerwanie zajmuja w tym zestawieniu druga pozycję, sukcesywnie powiększając przewagę nad resztą stawki oraz niwelując dystans do amerykańskiego lidera ${ }^{1}$. W 2017 r. różnica ta wynosiła już tylko 2,83 mld dolarów, przy wyniku 
11,10 mld dolarów ${ }^{2}$ wpływów osiągniętych na rynku amerykańskim (US i Kanada) i zdaje się, że objęcie przez Chiny prowadzenia w tym zestawieniu jest tylko kwestią czasu. Warto też zauważyć, że w ciągu dwunastu miesięcy w Chinach przybyło prawie 10 tys. ekranów kinowych, które w 2017 r. osiągnęły liczbę 50 776. Oznacza to, że co godzinę każdego dnia przybywał jeden ekran. Dla porównania w USA liczba ekranów wynosiła w tym samym okresie 40393 . Tempo wzrostu rynku kinowego w Państwie Środka budzi podziw, trzeba tylko pamiętać, że w Chinach mieszka miliard osób więcej niż w Stanach Zjednoczonych, a zatem wraz z bogaceniem się chińskiego społeczeństwa ów rynek wciąż może się powiększać.

Istotna jest również liczba filmów fabularnych produkowanych przez największych graczy; w 2017 r. statystyka ta prezentowała się następująco: Indie - 1986 (przypadek, który należy analizować osobno w kontekście wewnętrznego przemysłu filmowego, wskazując na odmienne standardy produkcyjne i preferencje indyjskiej widowni), Chiny - 920, USA - 821, UE - 1676 (w tym m.in. Francja - 300, Niemcy - 247, Hiszpania - 247, Włochy - 235, Wielka Brytania - 212). Ważniejsze jednak pozostaje pytanie, które filmy przynoszą największy zysk, a tu odpowiedź nie pozostawia wątpliwości i mówi o zwycięstwie Amerykanów. Wśród dwudziestu najbardziej dochodowych tytułów roku 2017 dziewiętnaście pochodzi z Hollywood i tylko jeden jest produkcji chińskiej (Wolf Warrior 2, reż. Jing Wu, 2017). Należy przy tym zauważyć, że na liście tej znajdują się cztery koprodukcje chińsko-amerykańskie ${ }^{3}$, które stanowią przykład walki Hollywoodu o wpływy z rynku chińskiego, zamkniętego dla podmiotów zewnętrznych, na którym dominują rodzime produkcje. Co roku do dystrybucji w Chinach zostaje dopuszczonych tylko 38 filmów zagranicznych.

Wydaje się, że amerykański rynek kinowy zaczyna wchodzić w fazę stagnacji. By utrzymać poziom wpływów, Amerykanie są zmuszeni zdobywać przestrzeń rynkową Państwa Środka. Pomijając kwestie polityczne, Hollywood musi w zamian oddawać chińskiej kulturze znaczące miejsce w swoich filmach. Wynik tych zmagań jest trudny do przewidzenia, ale na razie Amerykanie wyraźnie prowadzą, a gwarantuje im to wiodąca pozycja na rynkach państw trzecich, w tym przede wszystkim europejskich. W 2017 r. wpływy Wielkiej Szóstki (20th Century Fox, Warner Bros., Paramount Pictures, Columbia Pictures, Universal Pictures i Walt Disney) na rynku Unii Europejskiej wyniosły 66,2 proc., filmy europejskie (w tym te wsparte przez kapitał amerykański) osiągnęły wynik 31,2 proc., a zatem tylko 2,6 proc. stanowiły tytuły spoza tego układu.

Amerykańska koprodukcja filmowa z niektórymi krajami europejskimi jest wynikiem przede wszystkim korzystnej dla obu stron kalkulacji ekonomicznej i gospodarczej. Hollywood może na Starym Kontynencie produkować taniej, a dodatkowo liczyć na wiele zachęt finansowych, związanych między innymi z ulgami i odpisami podatkowymi. Kapitał amerykański wpływa z kolei na rozwój sektora usług przemysłu filmowego w Europie, a także podnosi prestiż regionu w danym kraju. Co w takim razie mają do zaoferowania kinematografiom europejskim Chińczycy i czy ich gotowość do międzynarodowych kooperacji nie jest przypadkiem elementem walki o istotne wpływy na rynkach państw trzecich? 


\section{Specyfika koprodukcji filmowej z Chinami}

W standardach współpracy produkcyjnej na świecie, również tej z Chinami, wyróżniamy trzy kategorie: koprodukowanie, asystowanie i zlecanie. Każdy z tych kontraktów może być bilateralny lub wielostronny. Koprodukowanie dotyczy filmów, w których zarówno producent chiński, jak i zagraniczny wnoszą swój wkład produkcyjny na określonych zasadach, czy to w postaci finansowej, materialnej czy jeszcze innej, i wspólnie ponoszą odpowiedzialność za powstające dzieło oraz nabywają do niego praw majątkowych. Dzielą się zarówno korzyściami, jak i ryzykiem związanym z całym procesem produkcyjnym. Koprodukcja asystująca polega na tym, że zagraniczny podmiot odpowiedzialny za produkcję, kręcąc film na terytorium Chin, prosi o wsparcie lokalnego producenta. Owa asysta może dotyczyć wyboru lokacji, uporania się z formalnościami koniecznymi do rozpoczęcia zdjęć lub zwykłą logistyką całego procesu. Producent asystujący nie nabywa jednak żadnych praw autorskich i majątkowych do realizowanego filmu. Zlecenie koprodukcyjne dotyczy zaś przypadków, w których producent filmu powierza wykonanie części lub całości zdjęć producentowi z Chin według precyzyjnych wytycznych artystycznych i określonych warunków technicznych. Producent realizujący zlecenie również nie ma żadnych praw do filmu, ale podobnie jak producent asystujący otrzymuje ekwiwalent w postaci zapłaty za wykonane zlecenie.

Aby koprodukowanie z Chinami było w ogóle możliwe formalnie, lokalni decydenci musieli opracować wiele ustaw określających warunki i zasady funkcjonowania chińskiej kinematografii. Pierwsze regulacje na tym gruncie dotyczyły administracji ${ }^{4}$. Prawa dotyczące powstających scenariuszy spisano natomiast w 2006 r. w ustawie The Regulations on Movie Scripts (Summary) Registering and Movies Administration. Większość zapisów w niej zawartych dotyczyła spraw związanych z cenzurą. Ta jednak, co warto podkreślić, częściej dotyczy konwenansów kulturowych niż kwestii politycznych. Chińczycy chcieli też dość szybko (jeśli weźmiemy pod uwagę inne uchwały) uregulować sprawy związane z koprodukcją międzynarodową. W 2004 r. powstał dokument The Administration of Sino-Foreign Cooperation in the Production of Films Provisions ${ }^{5}$ zaakceptowany przez Komitet Centralny Komunistycznej Partii Chin. Do jego najważniejszych zapisów należą: artykuł 2, określający status producenta chińskiego mogącego brać udział w koprodukcji, który uzyskał zezwolenie na produkcje filmowa, i w konsekwencji artykuł 7, który wszystkim podmiotom zabrania angażowania się bez takiego zezwolenia w produkcję filmową na terytorium Państwa Środka. Punkt ten nie pozwala również na podejmowanie niezależnych działań produkcyjnych przez producenta zagranicznego bez zaangażowania partnera chińskiego lub specjalnego zezwolenia wydanego przez Partię. Artykuł 12 oznajmia, że zezwolenie na zagraniczną koprodukcję wydawane jest na dwa lata, co oznacza, że w tym czasie wszystkie prace produkcyjne powinny zostać ukończone. Artykuł 16 zaś zaznacza, że żadna produkcja sino-zagraniczna nie może być wyświetlana i dystrybuowana w Chinach oraz na rynkach zagranicznych bez poddania się ocenie i pozytywnej weryfikacji przez odpowiednie instytucje administracji państwowej.

Najważniejszym organem odpowiedzialnym za sprawy chińskiej kinematografii jest SARFT, w 2014 r. przemianowany na SAPPRFT (State Administration of Press, Publication, Radio, Film and Television). Podmiot ten ma także jednostki 
lokalne działające w poszczególnych prowincjach i przejmujące na siebie część obowiązków, szczególnie związanych z cenzurą. Instytucją odpowiadającą wyłącznie za sprawy koprodukcji międzynarodowych jest China Film Co-Production Corporation (CFCC) powstała w 1999 r., obecnie będąca również największym dystrybutorem działającym na terenie Chin ${ }^{6}$.

Procedura uzyskania oficjalnego statusu koprodukcji chińskiej (dotyczy koprodukowania i asystowania) sprowadza się do trzech etapów: zgłaszania projektu, okresu zdjęciowego i oceny ukończonego filmu, z czego najtrudniejszy wydaje się etap ostatni. Kiedy film zostanie już ukończony, obraz poddaje się finalnej weryfikacji. Liczba pojedyncza nie jest tu być może najbardziej fortunna, ponieważ to proces wieloetapowy, gdzie kolejne departamenty CFCC oglądają i wydają opinię na temat dzieła. Przypomina to ścieżkę kolaudacyjną, na której obraz może: zostać przyjęty bez poprawek; przyjęty, ale po dokonaniu precyzyjnie określonych zmian lub wymagający znacznych korekt, co oznacza odrzucenie filmu i konieczność powtórnego przejścia procesu akceptacji.

W Chinach istnieje kilka źródeł wsparcia produkcji filmowej, z których mogą korzystać także twórcy zagraniczni realizujący filmy we współpracy z lokalnymi podmiotami. Podstawową formą finansowania jest oczywiście inwestycja bezpośrednia, pokrywana ze środków własnych producenta. W przypadku ich braku można liczyć na dobrze zorganizowane pożyczki bankowe, coraz chętniej przyznawane przez instytucje finansowe ze względu na zabezpieczenia, które gwarantuje chiński rząd w dokumencie The Circular on Supporting Several Economic Policies for Film Industry Development. Państwo Środka oferuje także bardzo dobrze rozwiniętą sieć funduszy, z których mogą korzystać filmowcy. Nie wszystkie są przeznaczone wyłącznie dla kinematografii, wiele z nich wspiera szeroko pojętą politykę kulturalną kraju. Różne są też źródła finansowania samych funduszy. Niektóre z nich wspiera bezpośrednio rząd, inne czerpią ze środków prywatnych lub kapitałów chińskich spółek. Dobrze rozwinięte jest również finansowanie filmu za pomocą product placement, ograniczające ryzyko ekonomiczne, ponieważ oparte na inwestycji marketingowej danej firmy. Coraz popularniejsze jest „finansowanie sieciowe”, czyli przede wszystkim crowdfunding, oparty na wpłatach dokonywanych przez prywatne podmioty za pomocą platform internetowych. W ten sposób sfinansowano koprodukcję chińsko-francuską Wilczy Totem (reż. Jean-Jacques Annaud, 2015). Film ten może stanowić dobry pretekst, by przejść do omówienia, jak te formalne zapisy wyglądają w praktyce koprodukcji sino-europejskich.

\section{Europejskie porozumienia koprodukcyjne z Chinami}

Europa w drugiej dekadzie XXI w. liczy 46 państw. Do czerwca 2019 r. porozumienia o koprodukcji z Chinami podpisało dziesięć krajów: Belgia, Dania, Estonia, Francja, Hiszpania, Holandia, Luksemburg, Malta, Wielka Brytania i Włochy. Nie ma zatem w tej grupie największej gospodarki europejskiej, czyli Niemiec (stan na październik 2019 r.), które wciąż negocjują z Chinami umowę, bez pewności, że uda im się dojść do porozumienia. Przyczyn takiego stanu rzeczy należy zapewne upatrywać w systemie finansowania niemieckiego kina, które jest zależne nie tylko od instytucji federalnej, ale w równym stopniu od silnych fundu- 
szy filmowych funkcjonujących niezależnie w prawie wszystkich landach. Zawarcie dwustronnej umowy jest więc zależne od kilku najmocniejszych niemieckich podmiotów finansujących, z których każdy walczy o satysfakcjonujące ich zapisy.

Za tworzenie sieci kontaktów chińsko-europejskich odpowiada między innymi stowarzyszenie Bridging the Dragon, organizujące spotkania producentów z Europy i Chin na najważniejszych festiwalach filmowych na świecie, w tym między innymi na niemieckim Berlinale. Polityka coraz bliższych relacji w tej dziedzinie jest wynikiem zależności gospodarczych. Dla Chin rynek Unii Europejskiej był w 2017 r. największym polem zbytu towarów, a Chiny dla UE są pod tym względem na miejscu drugim, ustępując jedynie Stanom Zjednoczonym. Wymiana dóbr między Chinami a UE jest warta dziennie półtora miliarda euro ${ }^{7}$. Czy jednak bilateralne porozumienia o koprodukcji filmowej między krajami europejskimi a Państwem Środka rzeczywiście mają sens, skoro rynek kinowy w Chinach jest wciąż tak zamknięty i jednocześnie tak niewiele filmów chińskich jest obecnych na europejskich ekranach?

Jeżeli założeniem Rady Europy jest osiagnięcie większej jedności między jej członkami, w szczególności ochrona i wcielanie w życie ideałów i zasad stanowiacych ich wspólne dziedzictwo ${ }^{8}$, to porozumienia zawierane między krajami członkowskimi a Państwem Środka należy traktować jako rozszerzenie tych działań w ujęciu globalnym. Przyjęcie wspólnej konwencji europejskiej o koprodukcji filmowej, określającej warunki i tryb działania, zmniejszyło ograniczenia i ułatwiło współpracę w dziedzinie produkcji filmowej na Starym Kontynencie. Brak jednego porozumienia między krajami europejskimi a Chinami oznacza natomiast, że każdy kraj musi warunki tej kooperacji wypracować indywidualnie. Należy przy tym pamiętać, że Europejska Konwencja o Koprodukcji Filmowej ma zastosowanie w przypadku koprodukcji wielostronnej, w której poza co najmniej trzema stronami z państw europejskich dopuszcza się udział koproducenta spoza tej wspólnoty.

Aby spełnić warunki definicyjne europejskiego utworu kinematograficznego, film musi zawierać „składniki europejskie” zgodnie z kryteriami, które potwierdzą jego „europejską tożsamość” - chodzi tu przede wszystkim o pochodzenie osób należących do grupy twórczej ${ }^{9}$. Kluczowy wydaje się jednak sam scenariusz, który wyraża ową tożsamość i bez względu na narodowość filmowców czy miejsce realizacji zdjęć zapewnia filmowi status europejskiego utworu kinematograficznego. W takim przypadku zaangażowanie Chin w koprodukcję międzynarodową oznacza, że dzieło musi mieć dodatkowe walory, istotne z ich perspektywy. Dla chińskiego rynku kinowego taki obraz ma status filmu zagranicznego, a więc musi przejść surową selekcję. By film był zwolniony z tej procedury, musi uzyskać status produkcji chińskiej, a to europejskiemu producentowi może gwarantować przede wszystkim dwustronna koprodukcja z Państwem Środka, często możliwa tylko na bazie zawartego porozumienia.

Poszukując pierwszego w historii przykładu współpracy filmowej kraju europejskiego z Chinami, poza chińsko-radzieckimi dokumentami z początku lat 50., trafiłem na obraz Latawiec z końca świata (Le cerf-volant du bout du monde, reż. Roger Pigaut, Kia-yi Wang, 1958). To produkcja francusko-chińska, której akcja dzięki podróży młodego rodzeństwa, w jaką zabiera je magiczny chiński latawiec - rozpoczyna się na przedmieściach Paryża, a kończy w historycznym Pekinie. Promocja kultury Państwa Środka wśród Europejczyków i reszty świata stanowi 


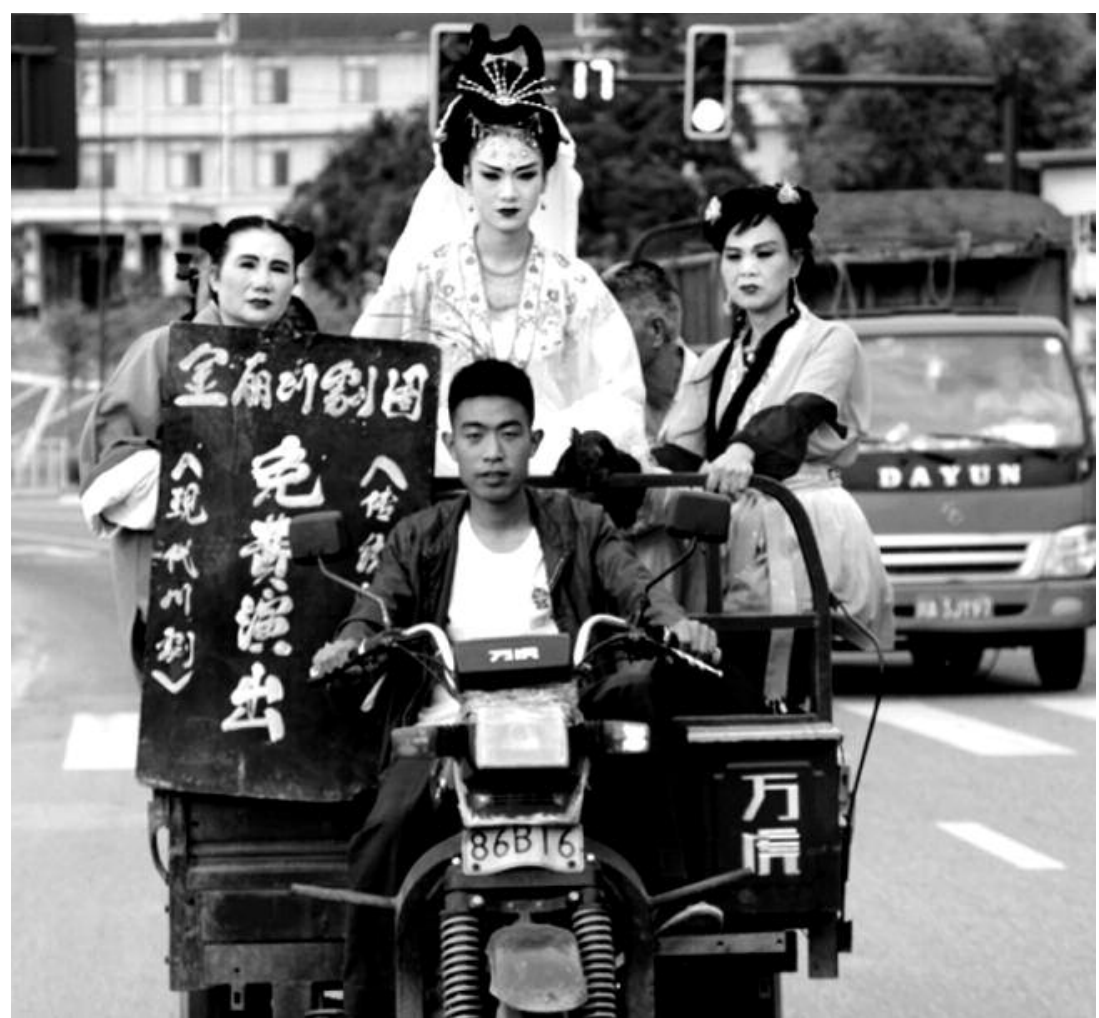

To Live To Sing / Huo zhe chang zhe, reż. Johnny Ma (2019)

do dziś podstawę realizacji takich projektów i jest bez wątpienia pośrednim celem, który chce osiągnąć chińska kinematografia.

Kolejna europejska produkcja, która uzyskała pozwolenie na zdjęcia w Chinach, powstała dopiero w latach 80., kiedy to Bernardo Bertolucci realizował Ostatniego cesarza (The Last Emperor, 1987), nagrodzonego dziewięcioma Oscarami. Ówczesny czytelnik polskiej prasy filmowej mógł, dzięki miesięcznikowi DKF-ów, poznać kilka szczegółów logistyki tej produkcji: Ostatni cesarz - zaplanowany na początku 1984 roku przez Bernardo Bertolucciego i jego scenarzystę Marka Peploe, którzy w marcu tego samego roku udali się w podróż do Pekinu, by nawiąać kontakty, wyprodukowany przez Jeremy'ego Thomasa - wymagat trzech lat przygotowań, kręcenia i technicznego wykończenia. Zdjęcia rozpoczęto 4 sierpnia 1984 roku w Zakazanym Mieście, zaś produkcję zakończono we wrześniu 1987 roku po wielu ,poprawkach” montażowych. Ekipa spędziła cztery miesiace w Chinach, kręcac plenery $w$ Pekinie, Dalian $i$ Changchun $w$ Mandżurii, oraz dwa miesiace w studio Cinecitta w Rzymie, kręcac wnętrza. Wytwórnie chińskie zatrudnity miejscowych techników i robotników organizując ich prace, pobyt $i$ wyżywienie wedlug własnych zasad. Niemalze wszystkie moce studiów w Pekinie zostały zmobilizowane dla filmu Bertolucciego, podczas gdy zwykle produkuje się w nich od piętnastu do dwudziestu filmów rocznie ${ }^{10}$. Podziw budzi do dziś nie tylko rozmach inscenizacyjny filmu Bertolucciego, ale także skala produkcji, którą udało się z sukcesem doprowadzić do końca. 
Pierwszym krajem europejskim, który zawarł porozumienie koprodukcyjne z Chinami, były Włochy. Umowę podpisano w 2004 r. i można sądzić, że jej efektem był film Czerwone kwiatki (Kan shang qu hen mei, reż. Yuan Zhang, 2006). Produkcję tę należy jednak traktować przede wszystkim jako wynik współpracy włoskiego producenta Marco Muellera i reżysera filmu, którzy na koncie mieli już wspólny projekt zatytułowany Siedemnaście lat (Guo nian hui jia, reż. Yuan Zhang, 1999). Oba te filmy mają status chińsko-włoskiej produkcji, w której strona z Półwyspu Apenińskiego była koproducentem mniejszościowym. Przypadek ten sugeruje, że samo porozumienie nie jest niezbędne, by film chińsko-europejski mógł w ogóle powstać.

Koprodukcją opartą na zawartym między Chinami i Włochami porozumieniu był obraz Caffè (reż. Cristiano Bortone, 2016). Jest to pierwszy z projektów, który został wpisany w strategię koprodukcyjną obu krajów w 2014 r. ${ }^{11}$ Cristiano Bortone jest tutaj postacią kluczową, o istotnym znaczeniu dla wszystkich chińsko-europejskich koprodukcji. Włoski reżyser jest bowiem dyrektorem zarządzającym organizacji Bridging the Dragon i największym zwolennikiem (wśród europejskich twórców) partnerstwa z Chinami. Jego entuzjazm utrzymuje się nawet pomimo frekwencyjnej porażki Caffè.

Bortone jest organizatorem sesji pitchingowych dla filmowców z Chin i Europy, które pomagają tworzyć sieci kontaktów. Jednak działania te wiążą się z ryzykiem i sceptycyzmem twórców, głównie po stronie europejskiej. Zasadniczą barierą jest tu zrozumienie preferencji chińskiej publiczności. Jeżeli głównym celem krajów europejskich, które podpisały porozumienie z Chinami, jest uzyskanie dostępu do chińskich kin, to najważniejszym zadaniem i największym wyzwaniem jest poznanie gustu lokalnego widza. Sytuację tę można odwrócić: jeśli Chińczycy chcą toczyć bój z Amerykanami o rynki państw trzecich, muszą lepiej rozumieć europejskiego widza. Nie można też wykluczyć, że wobec rozwoju rynków w Azji Wschodniej i Południowo-Wschodniej Chiny zaczną tracić na znaczeniu.

Za pierwszym z dwóch największych, jak do tej pory, sukcesów komercyjnych sino-europejskiej koprodukcji stoi kinematografia francuska - w 2015 r. Jean-Jacques Annaud we współpracy z Chinami zrealizował film Wolf Totem. Obraz zarobił we Francji skromne 8,8 mln dolarów, ale w Państwie Środka przekroczył kwotę $100 \mathrm{mln}{ }^{12}$. Annaud udało się osiągnąć tak dobry wynik zapewne dlatego, że odrzucił stereotypowe podejście do produkcji chińsko-europejskiej, zrezygnował z wątków kulturowych i postawił na uniwersalizm historii (konflikt natury i człowieka).

Francja, która podpisała porozumienie z Chinami w 2010 r., ma na koncie najwięcej koprodukcji z Państwem Środka, co nie powinno dziwić, jako że dysponuje największymi środkami na produkcję w całej Europie. Budżet francuskiego CNC (Centre national du cinéma et de l'image animée) wynosi średnio $700 \mathrm{mln}$ euro rocznie, dzięki którym powstaje ponad dwieście filmów. Co więcej, Francuzi biorą udział w wielu międzynarodowych projektach, na które w skali roku przeznaczają około 25 proc. całego budżetu ${ }^{13}$. Taki rozmach inwestycji w kinematografię jest nieosiągalny dla żadnego innego europejskiego kraju, nawet dla Niemiec, z którymi zresztą Francuzi koprodukują najczęściej. Należy jednak zauważyć, że procent zysków z dystrybucji francuskich filmów nieznacznie spada, a tendencja ta utrzymuje się już kilka lat. Próby zdobycia większych wpływów na rynku chińskim mają więc znaczenie strategiczne. Koprodukcja z Chinami niesie jednak ze sobą pewne pro- 
blemy, przede wszystkim w zakresie cenzury, przez którą francuskie projekty często nie uzyskują akceptacji, głównie ze względu na swobodne traktowanie kwestii obyczajowych. Kolejne bilateralne koprodukcje jednak powstają, czego przykładem mogą być filmy z ostatnich lat, jak Jezioro dzikich gęsi (Nan fang che zhan de ju hui, reż. Yi'nan Diao, 2019), To Live To Sing / Huo zhe chang zhe (reż. Johnny Ma, 2019), Dluga podróż dnia ku nocy (Di qiu zui hou de ye wan, reż. Gan Bi, 2018) czy Cisza we mgle (Chen wu, reż. Miaoyan Zhang, 2017).

Współpraca koprodukcyjna między Chinami a innymi krajami europejskimi, które podpisały porozumienie, wygląda gorzej. Hiszpania zawarła je w 2014 r., ale wciąż czeka, by jego zapisy mogły zostać zrealizowane. Za przykład bilateralnej koprodukcji nie można uznać filmu A Dog Barking at the Moon (reż. Lisa Zi Xiang, 2019), który co prawda powstał dzięki chińskim i hiszpańskim źródłom finansowania, ale został w całości wyprodukowany przez niezależną firmę Acorn Studio z siedzibą w Los Angeles, założoną przez chińską reżyserkę i hiszpańskiego autora zdjęć Jose Val Bala.

Kinematografia hiszpańska może się natomiast poszczycić specyficznym sukcesem na rynku chińskim, który osiągnął film Oriola Paulo Contratiempo (2016), mroczny i trzymający w napięciu kryminał. Obraz został w Chinach nielegalnie pobrany ponad milion razy ${ }^{14}$ i chociaż liczba ściągnięć hollywoodzkich blockbusterów jest dużo wyższa, a chiński rząd stara się ograniczać dostęp do pirackich stron, wynik ten zwraca uwagę i wskazuje na zaskakujące zainteresowanie hiszpańskim tytułem, nawet jeżeli kwestia dotyczy jedynie 0,1 proc. chińskiego społeczeństwa.

W koprodukcjach międzynarodowych Hiszpania często bierze udział jako partner mniejszościowy. Podobną rolę pełnią kraje Beneluksu. Wszystkie te państwa mają dobrze rozwinięty system publicznego wspierania finansowania produkcji filmowej, zarówno w postaci bezpośredniego wkładu finansowego, jak i zwrotów podatkowych. Pozwala to, szczególnie mniejszym kinematografiom, jak Luksemburg, na zaistnienie w międzynarodowym obiegu filmowym i promocję swojej kultury oraz gospodarki. Z kolei Belgia bierze udział w koprodukcjach międzynarodowych, umiejętnie korzystając z programów europejskich i własnych funduszy filmowych, pozwalających na zaangażowanie mniejszościowe, ale niepozbawiające praw do czerpania zysków. 72 proc. belgijskich filmów ${ }^{15}$ powstałych w latach 1990-2018 to koprodukcje międzynarodowe, co najlepiej świadczy o strategii produkcyjnej kraju. Najczęściej do współpracy dochodzi na linii belgijsko-francuskiej, choć swoją obecność czasem zaznaczał również Luksemburg. Właśnie w takim układzie te trzy państwa najczęściej angażują się w koprodukcję z Chinami. Jako przykład mogą służyć tu takie tytuły, jak Mme Mills (reż. Sophie Marceau, 2018), Valerian i Miasto Tysiaca Planet (Valerian and the City of a Thousand Planet, reż. Luc Besson, 2017), Transporter: Nowa moc (The Transporter Refueled, reż. Camille Delamarre, 2015) czy animacja Little Big Panda (reż. Greg Manwaring, 2011). Co warte podkreślenia, twórcy tych filmów to przede wszystkim Francuzi (Marceau, Besson i Delamarre) i jeden Amerykanin (Manwaring), na stałe mieszkający w Niemczech.

Holandia podpisała z Chinami porozumienie koprodukcyjne w 2015 r., trzy lata po Belgii i dwa przed Luksemburgiem. Na jego mocy status koprodukcji chińsko-holenderskiej uzyskują filmy, które otrzymały finansowanie zarówno ze strony holenderskiej, jak i chińskiej, przy czym wkład finansowy jednej strony nie może 
być mniejszy niż 10 proc. i większy niż 90 proc. ${ }^{16}$. W ramach tej współpracy najczęściej powstają filmy dokumentalne, czego potwierdzeniem są: Chińskie Van Goghi (China’s Van Goghs, reż. Yu Haibo, Kiki Tianqi Yu, 2016), Otwarcie chińskich szaf (Inside the Chinese Closet, reż. Sophia Luvara, 2015) czy As Time Goes by in Shanghai (reż. Uli Gaulke, 2011).

Pozostałe kraje, takie jak Dania, Estonia czy Malta, pomimo podpisanych porozumień, nie doczekały się realizacji wspólnych projektów. Warto zauważyć, że w historii duńskiej kinematografii tylko dwóm filmom udało się zmieścić w selekcji 38 tytułów dopuszczanych każdego roku do dystrybucji na terenie Chin. Były to: Kandydat (Kandidaten, reż. Kasper Barfoed, 2008) i Wszystkowidząca (Skammerens datter, reż. Kenneth Kainz, 2015). Tak popularny w Europie hit Duńczyków Winni (Den skyldige, reż. Gustav Moller, 2018) nie doczekał się premiery na tamtejszym rynku, pomimo obowiązującego już porozumienia i zdawałoby się łatwiejszego dostępu do struktur chińskiego rynku kinowego. Na otwarciu chińskiego kina na światowych twórców skorzystał natomiast duński mistrz Bille August, który wyreżyserował międzynarodową produkcję Feng huo fang fei (2017).

Estonia do tej pory brała udział w tylko jednym projekcie z Chinami: wielostronnej koprodukcji z Finlandią i Holandią - Jade Warrior (reż. Antti-Jussi Annila, 2006) - wyświetlanej w ponad 70 chińskich miastach. Chociaż ówczesny estoński Minister Kultury Indrek Saar przekonywał, że Chiny potrzebują europejskiego rynku filmowego, europejskich planów filmowych i specjalistów z różnych dziedzin bioracych udział w procesie produkcji ${ }^{17}$, wydaje się, że Państwo Środka potrzebuje przede wszystkim terenu do promocji własnej kultury, którą najlepiej realizuje kino. Potwierdza to organizacja przeglądów chińskich filmów w niektórych krajach europejskich, jak Chinese Film Days w Estonii czy letni przegląd najnowszych chińskich produkcji na maltańskiej wyspie Gozo organizowany od $2007 \mathrm{r}$.

Ostatnim krajem, który wymaga choćby krótkiego omówienia, jest Wielka Brytania. Brytyjczycy są znani ze swojego zaangażowania w produkcje hollywoodzkie, które nieprzerwanie realizuje się w studiach Pinewood czy Sheperton. Amerykanie w dużym zakresie korzystają z talentów brytyjskich twórców i ekip filmowych, na czym często cierpi kino Brytyjczyków. Jednak to właśnie Zjednoczone Królestwo może się pochwalić drugim dużym sukcesem bilateralnej koprodukcji sino-europejskiej. Cudzoziemiec (reż. Martin Campbell, 2017) uchodzi za modelowy przykład filmu, który cieszył się popularnością zarówno na ekranach krajów europejskich, chińskich, jak i amerykańskich ${ }^{18}$. Nie był to jednak efekt zastosowania jakiejś tajemniczej formuły - przyczyną sukcesu było obsadzenie w głównych rolach Pierce'a Brosnana, czyli „emerytowanego Bonda” i Jackie Chana, międzynarodowej gwiazdy kina akcji. Do tego należy dodać trzymającą w napięciu historię wyreżyserowaną przez Martina Campbella, twórcę dwóch odsłon przygód Jamesa Bonda. Być może największym osiągnięciem producentów jest jednak to, że film został sklasyfikowany jako film chiński i nie musiał przechodzić wspomnianej selekcji dopuszczającej produkcje zagraniczne do dystrybucji na rynku chińskim. Inne przykłady współpracy między tymi dwoma krajami kryją się w koprodukcjach sino-hollywoodzkich, w których Brytyjczycy często biorą udział - wydaje się, że skala tych projektów nie zmieni się w wyniku Brexitu. Co ciekawe, kinematografia brytyjska była zaangażowana w dwie koprodukcje z Chinami, w których uczestniczyli także Polacy. 


\section{Chiny a sprawa polska}

Mimo że Polska nie podpisała żadnego oficjalnego porozumienia z Chinami, może się poszczycić trzema znaczącymi przykładami kooperacji filmowej z Państwem Środka. Należy jednak zaznaczyć, że tylko pierwszy tytuł stanowi czysty, bilateralny układ, a dwa pozostałe powstawały w wyniku współpracy wielostronnej, opartej na zasadach określonych przez opisaną już Europejską Konwencję o Koprodukcji Filmowej.

Koprodukcja Studia Filmowego „Zebra” i Changchun Film Studio, przy wsparciu finansowym Agencji Produkcji Filmowej, Telewizji Polskiej i Canal+, zatytułowana Kochankowie roku tygrysa (reż. Jacek Bromski, 2005), była realizowana od lipca do grudnia 2004 r. Sam okres zdjęciowy zamknął się w pięćdziesięciu dniach, a według oficjalnych danych budżet produkcji wyniósł jedynie $4 \mathrm{mln}$ zł. To niewiele, zważywszy na długość okresu zdjęciowego, historyczną scenografię oraz fakt, że całość materiału została zarejestrowana w Chinach. Wytłumaczeniem tak niskich kosztów może być to, że znaczną większość w ekipie realizacyjnej stanowili Chińczycy, a chińskim koproducentem było państwowe studio z ogromnym zapleczem usług i pracowników, których stawki nie były zbyt wysokie. Nieprzypadkowo też na lokację filmową została wybrana prowincja Jilin, która jest produkcyjną bazą Changchun Film Studio. Na pytanie, dlaczego Jacek Bromski zdecydował się na realizację filmu w Chinach, reżyser odpowiadał: Chiny i ich kultura fascynuja mnie od lat. Byłem w Chinach co najmniej kilkanaście razy, spędziłem $w$ sumie ponad rok $w$ różnych miastach i prowincjach i decyzja zrobienia tam filmu dojrzewała we mnie od dawna. Pociaga mnie niezwykła energia, która tam się unosi, przy której Europa wydaje się miejscem nie tyle dekadenckim, co po prostu zdziadziałym, hermetyczność tej kultury, która nigdy nie czerpała z kultury europejskiej, ani żadnej innej, wręcz przeciwnie, zamykała się na obce wptywy. Nie odważyłbym się robić filmu o Chinach inaczej, jak tylko z punktu widzenia Europejczyka. Wymyśliłem więc postać bohatera z naszego świata, który przedostaje się do świata egzotycznego - młodego Polaka, zesłańca uciekającego z Syberii. Scenariusz spodobat się chińskim producentom z Changchun, którzy zdecydowali się na produkcję filmu przy wspótpracy ze strona polska ${ }^{19}$.

Produkcja polsko-brytyjskiego studia Breakthru Films Latajaca maszyna (reż. Martin Clapp, Geoffrey Lindsey, 2011), realizowana w Łodzi w latach 2009-2011 20, powstała w wyniku współpracy kilku krajów: Polski, Wielkiej Brytanii, Norwegii, Indii i Chin. Państwo Środka nie było jednak pierwszym wyborem koproducenckim, najpierw film miał być realizowany wraz z firmą francuską. Jej właścicielowi nie udało się jednak zebrać pieniędzy na film, co wymusiło na producencie filmu - Hugh Welchmanie - konieczność szukania nowych źródeł finansowania. Było to konieczne, ponieważ zwiększały się koszty powstania filmu - projekt planowany pierwotnie jako krótkometrażowa animacja poklatkowa przekształcił się w pełnometrażową hybrydę aktorsko-animowaną. Zmiany te były podyktowane wymogami dystrybutora, który chciał wprowadzić film na ekrany kin.

Przy wyborze koproducenta najczęściej decydują walory scenariusza, z którym zagraniczny partner może się na jakimś poziomie utożsamić - najczęściej jest to tematyka lub miejsce akcji. W przypadku Latajacej maszyny o sprawie przesądzał przede wszystkim udział Lang Langa, wirtuoza fortepianu, który w Chinach jest 


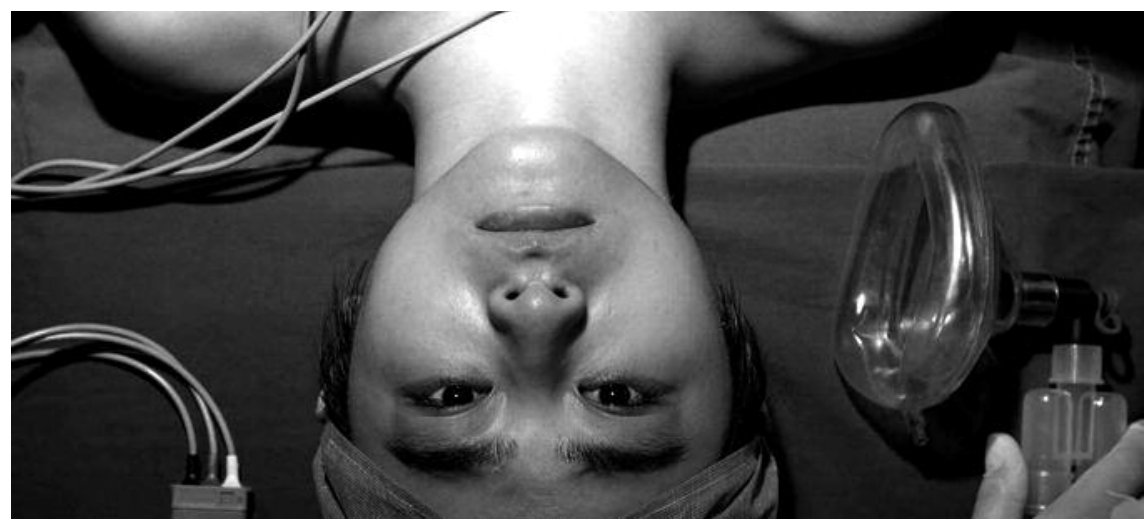

A Dog Barking at the Moon, reż. Lisa Zi Xiang (2019)

prawdziwą gwiazdą, a w filmie nie tylko wykonywał wszystkie partie muzyczne, ale także odgrywał jedną z głównych ról. Pianista stał się ambasadorem dzieła, zrealizowanym dla uczczenia 200. rocznicy urodzenia Fryderyka Chopina, również cenionego w Państwie Środka. Wszystkie te czynniki sprawiły, że prawdopodobieństwo znalezienia partnera w Chinach znacznie wzrosło. Po kilku wizytach w tym kraju Hugh Welchman mógł ogłosić, że nowym koproducentem została firma Bona Entertainment z siedzibą w Hongkongu. Umowa między Breakthru Films a Boną została zawarta 26 kwietnia 2010 r., kilka miesięcy po rozpoczęciu prac nad animacją i tuż przed okresem zdjęciowym do części aktorskiej. Na jej mocy chiński koproducent, po uzyskaniu akceptacji pozostałych stron, wystąpił do ówczesnego SARFT-u o uznanie Latającej maszyny za oficjalną koprodukcję chińską. Uroczysta premiera filmu odbyła się w październiku $2011 \mathrm{r}$. w sali koncertowej Zakazanego Miasta w Pekinie przy udziale polskich i chińskich przedstawicieli władz i świata kultury. Obraz nie cieszył się jednak zbyt dużą popularnością wśród widzów, zarówno chińskich, jak i europejskich. Walory kulturowe nie są więc żadną gwarancją sukcesu, a wpływ międzynarodowych koprodukcji na globalny rynek kinowy jest niewielki, jeśli wynikiem tej współpracy jest film, który nie zainteresuje widowni.

Ostatni na tej krótkiej liście doświadczeń chińsko-polskich jest film Tajemniczy sojusznik (Secret Sharer, reż. Peter Fudakowski, 2014), na podstawie opowiadania Josepha Conrada. Autorem zdjęć jest Michał Tywoniuk, który od 2009 r. stale pracuje na rynku chińskim. Strona polska była odpowiedzialna za prawie całą postprodukcję, czyli montaż, który wykonał Jarosław Barzan, oraz digitalizację, opracowanie dźwięku i obrazu, których podjęły się odpowiednio warszawskie studia Chimney, Dreamsound i Badi Badi FX. Dzięki takiemu rozwiązaniu producent mógł liczyć na wsparcie finansowe ze strony Polskiego Instytutu Sztuki Filmowej. Film zebrał jednak równie niewielu widzów, jak Latająca maszyna.

\section{Podsumowanie}

Poza dziełem Bernarda Bertolucciego żaden inny film powstały we współpracy chińsko-europejskiej nie wywarł większego wpływu na światowe kino. Trudno się temu dziwić, skoro celem tychże koprodukcji jest na razie budowanie relacji i pro- 
mocja chińskiej kultury. Amerykanie koprodukują z Chinami po to, by poprawiać swoje wyniki w globalnym box-office, co zapewnia im przede wszystkim dostęp do wewnętrznego rynku Państwa Środka. W tej rozgrywce to Chińczycy są stroną, która dyktuje warunki, to oni dysponują tym, na czym zależy producentom z Hollywood (przynajmniej dopóki nie rozwinie się rynek w Afryce czy Ameryce Południowej). Szefowie amerykańskich wytwórni godzą się nawet na nierówny podział wpływów - w Chinach zostaje około 60 proc. zysku z dystrybucji hollywoodzkich hitów. Dla kinematografii europejskich wyniki sprzedażowe nie mają tak dużego znaczenia, ponieważ dla nich liczy się przede wszystkim stały dostęp do źródeł finansowania kolejnych projektów. Możliwość koprodukowania ze stroną chińską to szansa na zdobycie dodatkowych środków na produkcję. Z kolei motywacją Chin do zawierania takich porozumień jest przede wszystkim próba umiędzynarodowienia swojego kina, które ma świetną pozycję na rynku wewnętrznym, a jest praktycznie nieznane poza Azją. Ponadto chińska kinematografia nie tylko czerpie sprawdzone wzorce z kina amerykańskiego, ale także próbuje podnieść wartość artystyczną własnych produkcji, spoglądając na kino europejskie. Do tego dochodzi wspomniane budowanie relacji między Europą a Chinami, które poza wymianą handlową powinny rozwijać się także na polu kultury. Jeżeli w Europie powstaje zbyt mało takich koprodukcji, to zapewne dlatego, że twórcom brak nośnych pomysłów albo też zgłoszone projekty nie spotykają się z akceptacją chińskich decydentów. Z kolei te już wyprodukowane nie przyciągają uwagi szerokiej publiczności ani w Europie, ani w Chinach. Warto jednak pamiętać, że dla kinematografii, które nie mogą konkurować z amerykańskim przemysłem filmowym, które nie mają większego znaczenia na globalnym rynku kinowym, każda szansa na umiędzynarodowienie produkcji stwarza perspektywę wyjścia poza ograniczenia rodzimego rynku. To sposobność do uzyskania pewnego prestiżu, za którym czasem stoi sukces finansowy, a czasem artystyczny.

Czy istnieje prawdopodobieństwo, że za parę lat w europejskich kinach będą dominować filmy produkowane w Chinach? Jest to możliwe, ale przypuszczalnie będzie to wynikać z uwarunkowań ekonomicznych lub migracyjnych: albo Chiny zainwestują ogromne środki finansowe w promocję swojego kina na Starym Kontynencie, albo zainteresowanie nim wzrośnie wraz z przybyciem ludności chińskiej do Europy. Dziś Chiny są skupione przede wszystkim na umacnianiu swojej pozycji na rynku wewnętrznym. Trzeba przy tym pamiętać, że w ostatnich kilku latach rynek audiowizualny bardzo się zmienił - o ile jeszcze dziesięć lat temu to właśnie kino budowało relację z widzem i było głównym źródłem zysków, o tyle dzisiaj w dużym stopniu odpowiadają za to również platformy streamingowe. Tak więc odpowiedź na pytanie, czy w przyszłości Sinowood zdominuje Hollywood na rynkach państw trzecich, nie jest już kluczowa, ponieważ bitwa zaczyna przenosić się do sieci. Analogicznie do rynku kinowego, Netflix nie jest dostępny w Chinach, gdzie jest rozwijany lokalny serwis iQiyi, skutecznie blokujący treści uważane przez władze za niepożądane.

Można więc stwierdzić, że Chinom, owszem, zależy na rozszerzaniu własnych wpływów w krajach zachodnich, na rozwijaniu współpracy, dzieleniu się kapitałem, ale wymagają dostosowania się do swoich zasad i przestrzegania narzuconych reguł, co w przypadku kultury i sztuki nie zawsze jest do pogodzenia. Chiny koncentrują się przede wszystkim na rozbudowywaniu rynku wewnętrznego, a wszyst- 
kie inne działania traktują jako element wojny handlowej i gospodarczej, którą od lat prowadzą ze Stanami Zjednoczonymi. Nawet jeśli przegrywają batalię na gruncie kultury audiowizualnej, to prawdopodobnie wygrywają ją na innych polach.

TOMASZ KOŻUCHOWSKI

${ }^{1}$ M. Adamczak, Kapitaty przemystu filmowego. Hollywood, Europa, Chiny, PWN, Warszawa 2019, s. 180-181.

${ }^{2}$ Wszystkie dane, chyba że zaznaczę inaczej, podaję za Focus 2018 World Film Market Trends, European Audiovisual Observatory.

${ }^{3}$ Szybcy $i$ wściekli 8 (The Fate of the Furious, reż. F. Gary Grey, 2017), Wonder Woman (reż. Patty Jenkins, 2017), Transformers: Ostatni Rycerz (Transformers: The Last Knight, reż. Michael Bay, 2017) i Kong: Wyspa Czaszki (Kong: Skull Island, reż. Jordan Vogt-Roberts, 2017).

${ }^{4} \mathrm{~W}$ grudniu $2001 \mathrm{r}$. został uchwalony pierwszy dokument tego typu, a mianowicie The Regulations on the Administration of Movies.

${ }^{5}$ Dokument dostępny online: http://www.fdi.gov.cn/1800000121_39_1313_0_7.html (dostęp: 13.12.2019).

${ }^{6}$ Na podstawie danych zawartych w China Film Industry Report 2014-2015 (In Brief), dostępnym online http://english.entgroup.cn/uploads/reports/China $\% 20$ Film $\% 20$ Industry $\% 20 \mathrm{R}$ eport $\% 202014-2015 \%$ EF\%BC\%88in\%20brief\%EF\%BC\%89.pdf (dostęp: 18.07.2019).

${ }^{7}$ A. Saarela, A new era in EU-China relations: more wide-ranging strategic cooperation? European Parliament 2018, s. 12.

${ }^{8}$ Zob: Preambuła Europejskiej Konwencji o Koprodukcji Filmowej z 2 października 1992 r.

${ }^{9}$ Program wsparcia międzynarodowych koprodukcji Eurimages określa ,europejskie pochodzenie" filmu za pomocą punktacji, w której projekty muszą uzyskać przynajmniej 15 z 19 punktów, zgodnie z tabelą punktową: reżyser 3 ; scenarzysta 3 ; kompozytor 1; rola pierwszoplanowa 3 ; rola drugoplanowa 2 ; rola trzecioplanowa 1 ; operator 1 ; realizator nagrań i operator dźwięku 1; montażysta 1; scenograf i kostiumograf 1; lokalizacja studia / zdjęć 1; realizacja postprodukcji 1; razem 19 punktów.

${ }^{10}$ M. Tessier, Logistyka filmu, tłum. M. Stafiej-Wróblewska, „Film na Świecie” 1988, nr 57-58 , s. 94.
${ }^{11}$ A. Butcher, Legendary Italian filmmaker looks to China co-productions, https://gbtimes.com/legendary-italian-filmmaker-lookschina-co-productions (dostęp: 10.09.2019).

${ }^{12}$ Średnia cena biletu do kina w Chinach wynosi 5 dolarów, co oznacza, że film mogło obejrzeć około 20 mln widzów. Biorąc pod uwagę liczbę mieszkańców, najpopularniejszą koprodukcję sino-europejską widziało 1,5\% chińskiego społeczeństwa.

${ }^{13}$ F. Bredin, Bilan cinéma 2018: une production unique en Europe, https://www.cnc.fr/professionnels/actualites/bilan-cinema-2018 - uneproduction-unique-en-europe_959242 (dostęp: 25.09.2019).

${ }^{14} \mathrm{G}$. Belinchon, Spanish cinema makes a splash in China, https://elpais.com/elpais/2019/04/22/inenglish/1555924771_812975.html (dostęp: 05.10.2019).

${ }^{15} \mathrm{~S}$. Follows, Which countries most commonly team up to create film co-productions? https://stephenfollows.com/most-frequent-coproducing-nations/ (dostęp: 10.09.2019).

${ }^{16}$ S. Roxborough, China, Netherlands Sign Coproduction Treaty, https://www.hollywoodreporter.com/news/china-netherlands-sign-production-treaty-834789 (dostęp: 12.09.2019).

${ }^{17}$ Estonia-China cooperation agreement promotes film industries of both countries, https://www.kul.ee/en/news/estonia-chinacooperation-agreement-promotes-filmindustries-both-countries (dostęp: 13.09.2019).

${ }^{18}$ L. Shackleton, ,, The Foreigner": anatomy of a successful UK-China co-production, https://www.screendaily.com/features/the-foreigner-anatomy-of-a-successful-uk-china-coproduction/5127695.article (dostęp: 6.09.2019).

19 Jacek Bromski o filmie „Kochankowie Roku Tygrysa", https:/www.film.gildia.pl/filmy/kochankowie_roku_tygrysa/wywiad (dostęp: 3.06.2019).

${ }^{20} \mathrm{~W}$ tym czasie pełniłem funkcję asystenta produkcji i asystenta producentów Latającej maszyny. 